\title{
EDITORIAL
}

DOI: http://dx.doi.org/10.1590/So034-759020180201

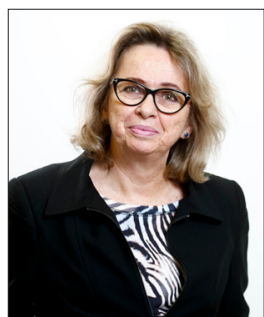

MARIA JosÉ TONELLI Editora-chefe

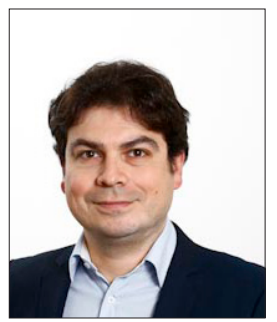

Felipe ZambaLdI Editor-adjunto

\section{WOMEN IN SCIENCE}

In March 2018, more than a century after the first manifestations of gender equality, we observe that the participation of women in science is still limited. Moschkovich and Almeida (2015) analyzed the teaching career data at Universidade Estadual de Campinas (UNICAMP) and revealed that although competitive admission claims to allow for an egalitarian selection of teachers, women are less likely to occupy higher positions within the university; moreover, while men are found across different areas, women are concentrated in specific areas of the institution and take more time to reach the top.

Valentova, Otta, Silva, and McElligott (2017), in a study with Conselho Nacional de Desenvolvimento Científico e Tecnológico (CNPq) scholars, showed that the proportion of senior female scientists in Brazil is still below the average found in other countries. The authors analyzed 13,625 productivity fellows and 3,836 researchers who received funds from the CNPq Edital Universal (Universal Call for Proposals) and concluded that women are less likely to reach the top of the career, and if they do, they take longer time than men. The lower index was found in the field of Life Sciences and Biomedicine, with slightly better indicators for Humanities and Social Sciences. The reasons for this under-representation can be attributed to our cultural and institutional roots. These data on the Brazilian reality are also observed in other countries, even though in this case, meritocracy seems to standardize the development of academic careers among men and women (see, for example, Cech \& Blair-Loy, 2010; Morley \& Walch, 2002, Settler et al., 2006). Albeit women are concentrated in Humanities and Social Sciences, this inequality is also evident in Business Administration (Vincenza, 2007).

Although there are several Qualis A2 Business Administration journals, for an initial conversation, we organized preliminary data from some journals and observed a significant difference in the publication of articles between men and women. Thus, we can affirm that women are still a minority in the authorship of scientific articles in the area, as evident from Table 1:

Table 1. Distribution of authorship in Business Administration journals - 2017

\begin{tabular}{l|c|c|c|c|c}
\hline & $\boldsymbol{R A E}$ & $\boldsymbol{R A P}$ & $\boldsymbol{R A C}$ & $\boldsymbol{R A U S P}$ & $\boldsymbol{R B G N}$ \\
\hline Men * & 80 & 89 & 70 & 71 & 52 \\
\hline Women * & 39 & 45 & 48 & 44 & 35 \\
\hline
\end{tabular}

Note: Data collected by Andréa Cerqueira and Ana Paula C. Soares, members of the RAE team, from the online editions published by these journals. It should be noted that the number of editions and articles published in the period analyzed is different for each journal. *Gender diversity was not considered in this collection, maintaining the traditional binary classification between men and women.

RAP-Revista de Administração Pública (Brazilian Journal of Public Administration) had the highest number of authors (134) in 2017, of which 89 (66\%) were males and 45 (34\%) were females. $R A E$ Revista de Administração de Empresas (Journal of Business Management) had a total of 119 authors, of which 80 (67\%) were male and 39 (33\%) were female. RAC-Revista de Administração Contemporânea had a total of 118 authors, of which 70 (59\%) were males and 48 (41\%) were females, the smallest gap between genders in 2017. RAUSP-Management Journal had 115 authors, of which 71 (62\%) were males and 44 (38\%) were females. RBGN-Review of Business Management had fewer editions throughout the 
year compared to the other journals: four editions and a total of 87 authors, 52 (60\%) males and 35 (40\%) females.

Although the perspective presented here only considers data of 2017 and a restricted group of publications in the Business Administration field, the results point to a predominance of male authors and agree with the trends presented by Valentova et al. (2017). Therefore, it is necessary to obtain indepth the knowledge on the participation of women in the Brazilian academic context of Business Administration.

In conclusion, many people question why so much emphasis is being placed on the discussion of women's presence in science or business. Therefore, it is important to reiterate that women's rights and their participation in all areas of knowledge are a matter of human rights and democracy.

Within the pluralistic approach of $R A E$, this edition presents articles from different areas of knowledge (Marketing, Finance, People Management, Organizational Studies, Entrepreneurship, Operations, and Logistics), as well as the Perspective section, in which Eduardo H. Diniz and Fábio Frezatti discuss the theme plagiarism in the Business Administration academic context. This issue is complemented by the review of the books Avaliação econômica de projetos sociais, by Naercio Menezes Filho, and Cultura do consumo: Fundamentos e formas contemporâneas by Isleide Arruda Fontenelle, and the book recommendation Governance \& charity: The benefits of corporate governance and charity association by Grazielle Rigotti da Silva.

Maria José Tonelli | ORCID: 0000-0002-6585-1493

Felipe Zambaldi | ORCID: 0000-0002-5378-6444

Fundação Getulio Vargas, Escola de Administração de Empresas de São Paulo - São Paulo - SP, Brasil

\section{REFERENCES}

Cech, E. A., \& Blair-Loy. M (2010). Perceiving glass ceilings? Meritocratic versus structural explanations of gender inequality among women in science and technology. Social Problems, 57(3), 371-397. doi:10.1525/ sp.2010.57.3.371

Morley, L., \& Walch, V. (Eds.) (2002). Feminist academics: creative agents for change, London, UK: Taylor and Francis.

Moschkovich, M., \& Almeida, A. M. F. (2015). Desigualdades de gênero na carreira acadêmica no Brasil. Dados, 58(3), 749-789. doi:10.1590/00115258201558

Settler, I. H., Cortina, L. M., Malley, J., Stewart, A. J. (2006). The climate for women in academic science: The good, the bad, and the changeable. Psychology of Women Quarterly, 30(1), 47-58. doi:10.1111/j.1471-6402.2006.00261.x

Valentova, J. V., Otta, E., Silva, M. L., \& McElligott, A. G. (2017). Underrepresentation of women in the senior levels of Brazilian science. PeerJ, (5), e4000. doi:10.7717/peerj.4000

Vincenza, P. (2007). Being female doing gender: Narratives of women in education management. Gender and Education, 19(1), 21-40. doi:10.1080/09540250601087728 